Ann. Biol. anim. Bioch. Biophys., 1979, 19 (3 A), 567-571.

\title{
Effect of milk composition on the gastrointestinal microflora of artificially reared young rabbits
}

\author{
par G. FONTY, Ph. GOUET, Y. RIOU \\ Laboratoire de Microbiologie, I.N.R.A. \\ Theix, Saint-Genès-Champanelle, 63110 Beaumont, France.
}

\begin{abstract}
Summary. The effect of artificial feeding and diet on the composition and development of digestive microflora was studied from birth to 14 days in young rabbits fed rabbit's milk and a cow milk substitute, respectively. The digestive microflora of those young animals artificially fed with rabbit's milk was comparable to that of rabbits nursed by the dam and artificial feeding caused no problems. The microflora was quantitatively and qualitatively perturbed in the young rabbits fed the cow milk substitute. Bacteria were more rapidly established than in the young nursed by their dam. Moreover, the stomach and small intestine harbored a large number of bacteria comparable to that of the colon $\left(10^{7}\right.$ to $10^{9} / \mathrm{g}$ ). The facultative anaerobic microflora became dominant at all levels of the digestive tract. Streptococcus and enterobacteria counts ranged between $10^{7}$ and $10^{9} / \mathrm{g}$ at all levels. No non-sporulated strict Gram-negative bacteria were found ; the major part of the anaerobic microflora was constituted of sporulated Gram-positive or Gram-negative bacteria. No lactobacillus was found. The young had great difficulty in absorbing the artificial milk, and they died before day 14 after birth. Owing to the originality of rabbit's milk and its effect on the microflora, it seemed impossible to use any milk, except maternal milk, to reproduce holoxenic rabbit microflora.
\end{abstract}

\section{Introduction.}

The study of host-microflora interactions and baterial balances within the digestive tract involves utilization of axenic and gnotoxenic animals. The production of axenic rabbits appears to be particularly difficult and is often unsuccessful. The progeny cannot be obtained from axenic parents, and newborns have to be artificially reared at each generation. The rate of rearing success is rather high when doe's milk is used (Appel et al., 1971 ; Riou et al., 1976 ; Dabard et al., 1976), but the collection of this milk is tedious and impractical when a large number of animals is raised. Thus, many authors have used milk substitutes generally having very empirical compositions and extremely limited possibilities as rearing feeds (Wostman and Pleasants, 1959 ; Schellenberg, 1976).

Feed affects the composition of digestive microflora. In rabbits, which have a peculiar milk composition and microflora, the changes caused by milk make it very difficult to study the autochtonous flora and its development concomitant with the 
age of young animals. The purpose of the present study was to analyze modifications in the gastrointestinal microflora of young conventional rabbits according to milk composition and animal age.

\section{Material and methods.}

\section{Artificial rearing of young rabbits.}

The effect of artificial rearing with doe's milk on intestinal microflora was studied on 5 conventional rabbits of the New Zealand breed 4, 5, 7, 10 and 14 days old, respectively. The doe's milk was collected with a milking machine (Lebas, 1970), homogeneized with a Polytron, and then frozen at $-80^{\circ} \mathrm{C}$. The young were separated from the dam at birth and nursed once a day with a teat-boftle containing milk heated to $30^{\circ} \mathrm{C}$. The amounts offered were those recommended by Lebas (1969).

A second series of $6 \mathrm{New}$ Zealand rabbits aged 2, 4, 6, 8, 10 and 12 days, respectively, was used to study the influence of the milk substitute on the microflora. The composition of this milk, obtained from ultrafiltrated cow's milk, was as follows: 23.8 p. 100 dry matter, 10.2 p. 100 fat, 11.7 p. 100 crude protein, 0.8 p. 100 lactose. The milk was freeze-dried, packed under vacuum in plastic bags, and then irradiated at $4.5 \mathrm{Mrad}$. After rehydration, it was offered in the previously described conditions and amounts in 3 meals per 24-hr period.

\section{Microbiological analysis.}

Samples from the stomach, small intestine and colon were microbiologically analyzed. The animals were killed and sampled; dilutions were made according to the previously described procedures (Gouet and Fonty, 1979). The total aerobic and anaerobic microfloras, enterobacteria, streptococci, lactobacilli, Clostridium and their spores, and sulfito-reducing Clostridium were studied using the same methods and the same media as previously described by Gouet and Fonty (1979).

\section{Results.}

1. Changes in gastrointestinal microflora in young rabbits artificially reared with doe's milk from birth until day 14 (fig. 1).

The bacterial counts showed that the flora was constantly present in the three organs; the number of facultative anaerobes was almost the same as that of the anaerobes.

The enterobacteria were one of the largest populations of the facultative anaerobic bacteria in the three organs of 3 rabbits aged 3,10 and 14 days, whereas they were absent at 4 and 7 days. The streptococci increased in the stomach and the small intestine until the age of 7 days, when they represented the largest group ; after that, they decreased to $10^{2} / \mathrm{g}$ at 14 days. The streptococci in the colon of all rabbits belonged to the dominant microflora. As in the rabbits nursed by their dam, this was the characteristic pattern of the microflora during the first and second week. No lactobacilli were found. 
The sporulated anaerobic bacteria counted on medium $D_{1}$ and on medium $B^{\prime}$ after heating were generally absent or scarce in the stomach or the small intestine. However, in the colon, they, with the streptococci, were one of the largest bacterial

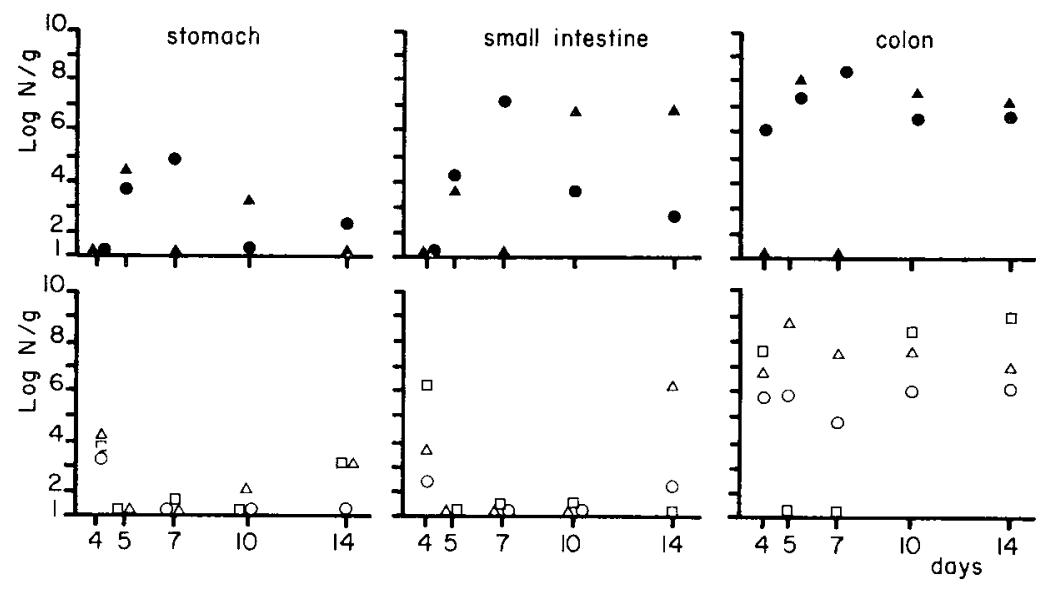

FIG. 1. - Changes in the gastro-intestinal microflora of rabbits artificially fed with do's milk.

- Streptococci ; Enterobacteria ; a Non-sporulated Gram-negative strict anaerobes ;

Anaerobic spores counted after heating on medium $B^{\prime} C ; \Delta$ Strictly anaerobic microflora counted on medium D1.

populations in all the rabbits $\left(10^{5}\right.$ to $\left.10^{6} / \mathrm{g}\right)$. The non-sporulated strictly anaerobic bacteria were always Gram-negative bacilli isolated at the highest dilutions from media $A$ and $B^{\prime}$; they constituted the preponderant part of the microflora of the three organs studied in 4-day old rabbits. These anaerobes were not found any more after that in the small intestine and very seldom in the stomach, and were absent from the colon on days 5 and 7 but present in greater number $\left(10^{8} / \mathrm{g}\right)$ on days 10 and 14 .

II. Changes in gastrointestinal microflora of young rabbits artificially reared with a milk substitute from birth until day 12 (fig. 2).

From the age of 2 days, the young rabbits harbored a relatively abundant flora in the whole digestive tract $\left(10^{4} / \mathrm{g}\right.$ in the stomach, $10^{5} / \mathrm{g}$ in the small intestine, $10^{6} / \mathrm{g}$ in the colon). These numbers then rapidly increased and stabilized at a high level in the three organs $\left(10^{7}\right.$ to $\left.10^{9} / \mathrm{g}\right)$.

Among the facultative anaerobic species, the enterobacteria (absent in rabbits aged 2 to 4 days) were established in a considerable and comparable number $\left(10^{7}\right.$ to $10^{9} / \mathrm{g}$ ) in the stomach, small intestine and colon ; they were one of the largest bacterial populations.

The streptococci were established a little earlier than the enterobacteria and reached the same numerical level. No lactobacilli were found.

The strictly anaerobic microflora was composed of sulfito-reducing Clostridium (mainly C. perfringens) and Endosporus. These bacteria were present in the three 
organs of all rabbits, except for the small intestine of one 4-day old rabbit. Their number increased until day 6 , then stabilized between $10^{5}$ and $10^{6} / \mathrm{g}$ in the stomach and the small intestine, and between $10^{6}$ and $10^{7} / \mathrm{g}$ in the colon.

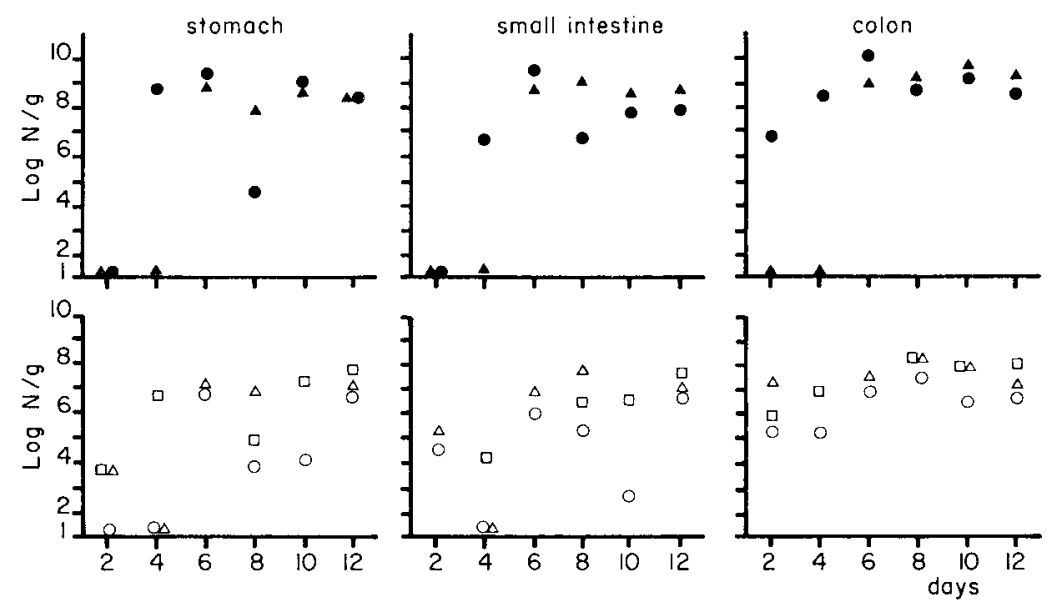

FIG. 2. - Changes in the gastro-intestinal microflora of rabbits artificially reared with a milk substifute.

- Streptococci ; $\triangle$ Enterobacteria ; $\square$ The colonies observed on this medium are generally sporulated ; 0 Anaerobic spores counted after heating on medium $B^{\prime} C ; \Delta$ Strictly anaerobic microflora counted on medium D1.

\section{Discussion.}

In terms of suckling and rearing, the rabbits fed with doe's milk presented no difficulties and had a regular growth. The predominance of streplococci during the first 2 weeks was the same as that observed in rabbits nursed by their dam (Govet and Fonty, 1979). However, the number of facultative anaerobes was higher; this result might be due to artificial rearing or to the absence of the dam, which could modify the microbial environment. It was very difficult to feed the milk substitute to the rabbits as the volumes consumed were very small and the feeding procedure long. A hard coagulum had already formed in the stomach after the second meal, and the animals showed very little weight increase; not one survived after day 14 . The main composants of the milk substitute were similar to those of doe's milk (Lebas, 1971), but there were large qualitative differences. Thus, according to Smith ef al. (1968), the fatty acids of doe's milk are constituted of 68 p. 100 octanoic and decanoic acids, 8 p. 100 palmitic acid and 18 p. 100 oleic and linoleic acids. On the contrary, cow's milk contains a lower percentage of short-chain acids; that of octanoic and decanoic acids do not exceed 4 p. 100 , whereas palmitic acids reaches 26 p. 100 and oleic and linoleic acids are close to 40 p. 100 . The composition of doe's milk casein does not seem to be very different from that of cow's milk (Testut and Ribadeau-Dumas, 1973), but it produces an extremely soft coagulum. Qualitatively and quantitatively, the microflora was entirely different from that of the rabbits nursed by their dam ; contrary Smith (1965), we never observed lactobacilli in rabbits fed cow's milk. 
In conclusion, the particularities of doe's milk are such that it is impossible to obtain a digestive microflora in gnotoxenic animals similar to that of holoxenic rabbits, if they are not fed this milk. Even then, artificial rearing causes changes in the microflora.

Reçu en avril 1978.

Accepté en novembre 1978.

Résumé. L'effet de l'allaitement artificiel et du régime alimentaire sur la composition et l'évolution de la microflore digestive a été étudié de la naissance à 14 jours chez des lapereaux respectivement nourris avec du lait de lapine et avec un lait de remplacement reconstitué à partir de lait de vache.

La microflore digestive des lapereaux allaités artificiellement avec du lait de lapine est comparable à celle des lapereaux nourris par la mère. En outre l'allaitement artificiel ne présente pas de difficultés.

Chez les lapereaux allaités avec le lait de remplacement on observe un bouleversement quantitatif et qualitatif de la microflore. L'implantation bactérienne est plus rapide que chez les lapereaux allaités par leur mère. De plus, l'estomac et l'intestin grêle hébergent dès les premiers jours un nombre de bactéries important ef comparable à celui du côlon $\left(10^{7}-10^{9} / g\right)$. La microflore anaérobie facultative devient dominante à tous les niveaux du tube digestif. Les streptocoques et les entérobactéries se situent entre $10^{7}$ et $10^{9} / \mathrm{g}$ dans tous les segments. Les bactéries anaérobies strictes non sporulées Gram négatives ne sont pas retrouvées, l'essentiel de la microflore anaérobie étant constituée de bactéries sporulées Gram positives et Gram négatives. Aucun lactobacille n'a été dénombré. Enfin, les lapereaux ont absorbé ce lait artificiel avec beaucoup de difficultés et ils sont morts le $14^{\mathrm{e}}$ jour au plus tard.

Les particularités du lait de lapine ef son influence sur la microflore sont telles qu'il semble impossible de pouvoir reproduire la microflore du lapereau holoxénique avec un autre aliment que le lait maternel.

\section{References}

APPEL K., BUSSE H., SCHULZ K., WILK W., 1971. Beitrag zur Handaufzucht von gnotobiotischen und S.P.F.-Kanichen. Z. Versuchstierk., 135, 282-290.

DABARD J., NOEL A., GRIGNON P., DESBRUERES P., 1976. Obtention et conditions de maintien du lapin dépourvu de germes pathogènes. 1er Congr. int. cunic., Dijon, Communic. $n^{0} 31$.

GOUET Ph., FONTY G., 1979. Changes in the digestive microflora of the holoxenic rabbit from birth until the adult age. Ann. Biol. anim. Bioch. Biophys., 19, 553-566.

LEBAS F., 1969. Alimentation lactée et croissance pondérale du lapin avant sevrage. Ann. Zoofech., 18, 197-108.

LEBAS F., 1970. Description d'une machine à traire les lapines. Ann. Zootech., 19, 223-228.

LEBAS F., 1971. Composition chimique du lait de lapine. Evolution au cours de la traite et en fonction de l'âge. Ann. Zootech., 20, 185-191.

RIOU Y., GOUET Ph., FONTY G., 1976. Mise au point d'une technique d'élevage de lapereaux axéniques ou gnotoxéniques. 1er Congr. Int. cunic., Dijon, Communic. $\mathrm{n}^{\circ} 32$.

SCHELLENBERG P., 1976. Création d'une souche de lapin «S.P.F. ». 1er Congr. int. cunic., Dijon, Communic. no 29.

SMITH H. W., 1965. The development of the flora of the alimentary tract in young animals. J. Path. Bact., 90, 495-513.

SMITH S., WATTS R.. DIES R., 1968. Quantitative gas liquid chromatographic analysis of rodent milk triglycerides. J. Lipid Res., 9, 52-57.

TESTUT M., RIBADEAU-DUMAS B., 1973. Etude des caséines du lait de lapine. Biochimie, 55, 10851093.

WOSTMAN B. S., PLEASANTS J. R., 1959. Rearing of germ free rabbits. Proc. Anim. Care Panel, 9, 47-54. 